TAD, C. 39/S. 67, 2020, s.529-549

\title{
PROPAGANDADAN GERÇEĞE: BROKEN HILL SALDIRISI
}

\author{
THE TRUTH FROM THE PROPAGANDA: THE BATTLE \\ OF BROKEN HILL
}

\author{
Makale Bilgisi \\ Başvuru: 25.09.2019 \\ Kabul: 02.10.2019
}

\section{Sinan KIYANÇ*}

\author{
Article Info \\ Received: September 25, 2019 \\ Accepted: October 02, 2020
}

\section{Özet}

Broken Hill Saldirlsı Avustralya tarihinde önemli bir yer tutmaktadır. Birinci Dünya Savaşı'nın hemen başında meydana gelen saldırı, ülkenin savaşa bakışını etkilemiştir. Birinci Dünya Savaşı'na karşı direncin kırılmasında son derece etkili olan saldırl hükümet tarafindan etkili bir propaganda unsuru haline getirilmiştir. Bu propaganda Birinci Dünya Savaşı'nda gönüllü asker katılıminın artışında önemli rol oynamıştı. İki Türk'ün masum sivillere saldırdığ yalanı üzerinde Düssman-Türk olgusu yaratılmış bu süreç Çanakkale Savaşıı'na kadar etkin bir şekilde sürdürülmüş̧ür. Broken Hill Saldırısı günümüze değin toplumsal hafiza da DüşmanTürk olgusuyla yer etmiştir. Çalı̧̧ma da yıllardır Avustralya'daki Düşman-Türk olgusu üzerinden propaganda olarak kullanılan Broken Hill Saldırısı'nın detayları ortaya konulmaktadır. Bu kapsam da saldırlyı aydınlatacak birinci el kaynaklar başta olmak üzere saldırı hakkında yazılmış eserler ele alınarak saldırının aslinın nasıl çarpittlarak bir propaganda malzemesi haline geldiği belirtilmektedir.

Anahtar Kelimeler: Avustralya, Broken Hill, Türk, Propaganda, Birinci Dünya Savaşı.

\section{Abstract}

The Battle of Broken Hill holds a important position in Australia's history. The attack at the outset of the First World War influenced Australian view of the war. It was an effective propaganda in the management of the attack, which was extremely

*Dr., Muğla Sitkı Koçman Üniversitesi, sinankiyanc@gmail.com 
effective in breaking the resistance of the First World War. This propaganda played an important role in the enlist of voluntery soldiers the First World War. Upon the lie of two Turks attacked innocent civilians, Enemy-Turk phenomenon was created and this process continued effectively until The Battle of Gallipoli. The Battle of Broken Hill had left a mark on until now in the social memory of the Enemy-Turk phenomenon. It is based on the starting of The Battle of Broken Hill, which is used with the propaganda of the Enemy-Turk phenomenon in Australia. This study is the first hand document regarding the battle and how the battle became a propaganda material by being distorted.

Key Words: Australia, Broken Hill, Turk, Propaganda, World War I.

\section{Giriş}

Birinci Dünya Savaşı, sıcak çatışmaların yanı sıra propaganda faaliyetlerinin de yoğun yaşandığ 1 bir süreç olmuştur. $\mathrm{Bu}$ süreç zarfında savaşın haklılığı ve asker sağlama konusunda propaganda önemli bir rol oynamıştır. Birinci Dünya Savaşı'na girildiğinde İngiltere, sömürgesi altında bulunduğu topraklarda uyguladığı yoğun propaganda sayesinde asker kaynağını artırmaya çalışmıştır. Bu çaba savaşın en uzak noktalarından birisi olan Avustralya'da tepkiyle karşılanmış, savaşa katılım İngiltere talebi doğrultusunda gerçeklememişti. Bu süreçte İngiltere'nin Avustralya'da yürüttüğü propagandalar etkisini artırarak devam etmiştir. ${ }^{1}$

İngiltere sömürgesi (The Commonwealth) olan Avustralya, Birinci Dünya Savaşı'nın başlamasıyla savaşa katılım konusunda tartışmalara sahne olmuştur. Birinci Dünya Savaşı'nı bir Avrupa Savaşı olarak gören Avustralya, savaşa katılmaya büyük direnç göstermiştir. İngiltere'nin yoğun propagandası ve Avustralya hükümetinin savaş yanlısı tutumu ülkedeki direnci kırmada etkili olmuştur. Avustralya topraklarında ilk terör saldırısı olan Broken Hill Saldırısı bölge insanının savaşa karşı direncini kırmada etkili olmuştur. Birinci Dünya Savaşı'nın hemen başında yaşanan saldırı, ülkenin savaşa bakışında önemli bir rol oynamıştır. Saldırının cihat uğruna iki Türk tarafından yapıldığ propagandası etkili olmuştu. Düşman-Türk olgusu üzerinden yürütülen propaganda Çanakkale Savaşı'na uzanan sürecinde başlangıcı olmuştur. Saldırı ülkede büyük yankı uyandırdığı gibi savaşa katılımı da artırmıştır.

Broken Hill'de saldırı tarihine kadar Avustralya'nın birçok yerinde olduğu gibi farklı dine ve dile mensup topluluklar iç içe yaşamıştır. Broken Hill'de beraber yaşayan topluluklar bu saldırı sonrasında nefret ve öfkeyle

1 Michael L. Sanders, "Wellington House and British Propaganda During the First World War", The Historical Journal, 1975, vol. 18, p. 130; Joan Beaumont, Broken Nation: Australians in the Great War, Sydney, Allen \& Unwin Publishing, 2013, s. 45. 
Alman kulübünü ateșe vermiș ve Ghantown olarak adlandırılan Afgan ve Hintli Müslüman devecilerin (sepoyların) bulunduğu kampı basmışlardı. Nihayetinde Savunma Bakanlığ 1 tarafından çıkarılan emirle Broken Hill'de bulunan Alman, Avusturyalı ve Türk (?) kısımlar Düşman Yabancılar ilan edilerek esir kampına gönderilmişlerdi. ${ }^{2} \mathrm{Bu}$ tepki o güne kadar kendilerine kilometrelerce uzakta yaşanan bir savaşa katılmakta pekte gönüllü olmayan Avustralya halk1 üzerinde derin bir etkiye neden olmuştur. Böylece gönüllü askerlik başvurularında önemli bir artış yaşanmış, Birinci Dünya Savaşı'nda Avustralya'dan en fazla asker katılımı Broken Hill'in bağlı olduğu Yeni Güney Galler eyaletinden gerçekleşmiştir.

Broken Hill Saldırısı Avustralya basınının bir kısmı tarafından önemli bir propaganda unsuru olarak kullanılmıştır. Görgü tanıkları saldırıda Gül Muhammed'e ait dondurma arabasını ve üzerinde kırmızı zemin üzerine ay ile yıldız olan bayrağın kullanıldığını ifade etmişlerdi. Bunun üzerine Osmanlı İmparatorluğu'nun bayrağının kullanıldığı basında geniş yer bulmuştu. Böylece saldırganların Türk oldukları ve saldırının, Osmanlı İmparatorluğu Sultanı, Halife tarafından ilan edilen cihat nedeniyle yapıldığ 1 iddia edilmiştir. Avustralya basını bu olayı sadece Osmanlı İmparatorluğu aleyhinde değil aynı zamanda Almanya aleyhinde de kullanmıştı. Avustralya'daki bazı basın kuruluşları olayın Almanya basını tarafından övüldüğünü, Alman basınında Avusturalya'da askerlerinin yaptığı saldırıda 40 ölü, 70 yaralı verdirdiği haberlerinin yer aldığını iddia etmiştir. ${ }^{3}$ Dahası Avustralya basını olayı Birinci Dünya Savaşı ile sınırlı bırakmamıştı. İkinci Dünya Savaşı yıllarında da Almanya karşıtı bir havaya neden olması için tekrar gündeme getirilmişti. ${ }^{4}$

Broken Hill Saldırısı'nın basında geniş yer tutması ve Düşman-Türk olgusunun güçlenmesine tepkilerde gecikmemiştir. Avustralya Osmanlı Birliği Başkanı S. J. Attiah'ın böylesine bir katliamı yapanların Osmanlı İmparatoru tebaasından ya da Türkler tarafından değil İngiltere egemenliğindeki bölgelerden gelen insanlar tarafından işlendiğini belirtmiştir. S. J. Attiah Düşman-Türk olgusu üzerinden Osmanlı İmparatorluğu'nu böylesine bir katliamla ilişkilendirmeden duyduğu rahatsızlığ açık bir şekilde ifade etmiştir. S. J. Attiah, Osmanlı İmparatorluğu'nun sadece Türklerden oluşmadığına dikkat çekmiş, Osmanlı İmparatorluğu'nun bünyesinde farklı

2 NSW Migration Heritage Centre, The Enemy At Home, German Internees in World War I Australia, http://www.migrationheritage.nsw.gov.au/ exhibition/enemyathome/battle-ofbroken-hill/index.html.

3 Bendigo Advertiser, "The Battle Of Broken Hill, German Official Account”, 26 Mart 1915, s. 5.

4 Brendan Whyte, “Propaganda Eats İtself: The 'bulletin' and The Battle of Broken Hill”, Sabretche Journal, 2016, vol. 57, ss. 48-57. 
ırktan ve dinden insanlar olduğunu belirtmiștir. Bunun yanı sıra saldırı da iddia edildiği üzere Türklerin Avustralya topraklarında bulunmadığını, Avustralya topraklarında bulunan Osmanlı İmparatorluğu tebaasının Lübnan'dan gelen insanlar olduğunun altını çizmiştir. ${ }^{5}$

S. J. Attiah'ın yoğun çabasına rağmen olayın Osmanlı İmparatorluğu tarafından cihat ilanı etkisinde olan iki Türk tarafından düşmanca bir saldırı olduğu inancı hâkim olmuştur. Toplumsal hafizada da bu olgu üzerinden yer etmiştir. Olaydan yıllar sonra bile bu olgu varlığını devam ettirmiştir. ${ }^{6} \mathrm{Bu}$ durum saldırı sonrasında yaşanan olaylara bakıldığında basının yanı sıra birçok alanda konu ele alınmıştır. Broken Hill Saldırısı hakkında ilk film 1981 yılında Tazmanya'da Battle of Broken Hill ismiyle çekilmiştir. Bunun yanı sıra War in Broken Hill belgeseli çekilmiştir. ${ }^{7}$ Avustralyalı müzik grubu Handsome Young Strangers'in 2016 yılında hazırladıkları albüme saldırının yüzüncü yılı anısına Battle of Broken Hill ismini vermişlerdir. Bunun yanı sıra Broken Hill Saldırısı edebiyat eserlerine de konu olmuştur. Nicholas Shakespeare tarafindan kaleme alınan Oddfellows ve Chris McCourt'un The Cleansing of Mahommed isimli eserlerde olay üzerinden kurgusal bir anlatım yapılmıştır. ${ }^{8}$

Broken Hill Saldırısı, Türkiye'de yıllar sonrasında haber yapılmış ve Kahraman-Türk olgusu üzerinden ele alınmıştır. Broken Hill Saldırısı, Birinci Dünya Savaşı'nda kilometrelerce uzaklıkta iki Türk tarafından gerçekleştirildiği yanılgısı hâkim olmuş, bir efsane haline gelmiştir. Bu yanılg1 Hikmet Feridun Es tarafindan 1967 yılı Haziran ayında yayınlanan Hayat Mecmuası'nda ele alınmasıyla başlamıştı. Hikmet Feridun Es'in kaleme alması sonrasında günümüze kadar birçok basın yayın kuruluşunda gerek yazılı gerekse görsel olarak haber yapılmıştır. Bu haberlerin birçoğunda olayın detayları yerine Kahraman-Türk olgusu hâkim olmuştur. Basında geniş yer bulan konu resmi makamları da harekete geçirmiştir. $\mathrm{Bu}$ yanılgının etkisinde kalan Türkiye'nin Kanberra büyükelçiliği 1990 yılının başında Broken Hill Saldırısı'nı gerçekleştirenleri sahiplenmiş, kemiklerinin iadesini istemiştir. Birkaç y1l sonra Avustralya'daki Türk topluluğu Broken Hill Meclisine başvurarak saldırıyı gerçekleştirenlerin Türk oldukları gerekçesiyle mezarların olduğu yerde bir anıt yapma taleplerini iletmişlerdi. Yapılacak

5 The Register, “Assailants Not Turks, Denial By Prominent Ottoman”, 2 Ocak 1915, s. 9.

Truth, "Truth reported the Turkish insurgency". 19 Aralık 1920, s. 9.

7 Ekrem Saltık, "1915'de Avustralya'da Bir Terör Saldırısı 'Kahramanlık' mı, Kompo mu?”, Toplumsal Tarih, 2011, S. 205, s. 89.

8 Nicholas Shakespeare, Oddfellows, Vintage Australia, Random House Publishing, 2015; Chris McCourt, The Cleaning of Mahommed, Sydney, Fourth Estate Publishing, 2012. 
anıtın projesi çizilmiş, görselleri hazırlanarak basınla paylaşılmıştı. Başvuru Broken Hill Belediye Meclisi tarafından kabul edilmemişti.

Broken Hill Saldırısı Avustralya'da bir nefret, Türkiye'de de bir kahramanlık hikâyesi olarak görülmesine karşın yakın zamanda hazırlanan bazı araştırmalarda saldırı araştırılmış detayları ortaya konulmaya çalışılmıştı. Broken Hill Saldırısı belgelerinin uzun bir süre ulusal güvenlik iddiasılya kamuoyuna açıklanmamış, sonrasında ise çıkan yangında yok olması olayın aydınlatılmasını zorlaştırmıştır. Bu nedenle hali hazırda saldırı ile ilgili birinci el kaynak Avustralya Basın Arşivi'dir. Avustralya Basın Arşivi'nden elde edilen bilgilerde gerek saldırının detaylar ve gerekse saldırı sonrasında başlatılan soruşturma hakkında önemli bilgiler barındırmaktadır.

Broken Hill Tarih Kurumu üyesi Gordon Densie'nin araştırmasında bazı dikkat çeken detaylar ortaya konulmaktadır. Gordon Densie, iddia edildiği gibi saldırıyı Türkler değil İngiltere egemenliğindeki Hintliler tarafından gerçekleştirildiğini belirtmiştir. Densie göre olay Birinci Dünya Savaşı'nda Avusturalya'da zorunlu askerlik olmadığından gönüllü asker toplamak için yapılan bir olaydı ve iki saldırgan kurban olarak seçilmişti. Saldırı konusunda şüpheli noktaları ortaya koyan Densie, Broken Hill Polis merkezinde bile sadece yedi silah bulunurken, saldırganların İngiliz ordusunun kullandığ 1 silahları nereden ve nasıl temin ettiği ortaya çıkarılmamıştır. Bu konuda Avustralya basınından elde edilen soruşturma bilgisinde silahların nasıl ve nereden temin edildiğine değinilmediği gibi Molla Abdullah'ın aldığı cezayı ödeyememesine karşın silahların ücretinin nasıl ödendiği ortaya çıkarılmamış, üzerinde durulmamıştır. ${ }^{10}$ Broken Hill Tarih Kurumu üyesi Gordon Densie'nin tespitine karşın Broken Hill Saldırısı sonrasında saldırganların öldürüldügü yer olan beyaz kayalarda (White Rocks) olayın anısına konulan yazıtta halen saldırının Türkler tarafından gerçekleştirdiği ifadeleri bulunmaktadır.

Türk kavramı Avustralya basının başlangıcından itibaren kullanılmıştı. İngiltere'nin sömürgesi olan Avustralya'da dünyayı nitelerken temel aldığı İngiltere basınında geçen kavramın bir yansıması olarak Türk kavramı kullanılmaya başlanmıştı. ${ }^{11} \mathrm{Bu}$ açıdan bakıldığında Osmanlı İmparatorluğu

9 Ömer Ertur, Derin Nefret, Anzakları Çanakkale Savaşı'na Sokan Komplo'nun Hikâyesi, Çeviren: Güneş Ayas, İstanbul, Donkişot Publishing, 2011, p. 7-8; Saltık, a.g.m., s. 89.

10 Recep Şakar, "Broken Hill Saldırısı Komplo mu?" http://www.hurriyet.com.tr/gundem/broken-hill-saldirisi-komplo-mu-21951919.

11 The Sydney Gazette and New South Wales Advertiser, "Extracts from the latest English Papers", 19 Haziran 1803, s. 2. 
ifadesi Türk ifadesinden sonraki yıllarda kullanılmıştır. ${ }^{12} \mathrm{Bu}$ açıdan bakıldığında Türk kavramı Osmanlı İmparatorluğu'nu temsil etmede kullanılmıştır. Broken Hill Saldırısı, Avustralya'nın Birinci Dünya Savaşı’na katılmayı da artırmıştı. 1915 yılı ülkede savaş havasının iyiden iyiye hissedildiği bir yıl olmuştu. Birinci Dünya Savaşı'na katılımın önemli oranda arttığı yılda Çanakkale Savaşı önemli bir yer tutmaktadır. Bu süreçte basında o güne kadar Osmanlı İmparatorluğu'nu tasvir ederken kullanılan Türk ifadesi Düşman olarak tanımlanmıştır. ${ }^{13}$

Günümüzde Broken Hill'de ve Sydney'deki müzelerde saldırıda kullanılan silahlar, cephane, Gül Muhammed'in dondurma satmada kullandığg arabanın benzeri, Molla Abdullah'a ait olan Kuran-i Kerim, saldırganlara ait olduğu iddia edilen mektuplar ve saldırı günü çekilen fotoğraflar -olayı canlı tutacak kanıtlar- sergilenmektedir. $\mathrm{Bu}$ kanıtların yanı sıra dönemi aydınlatacak fotoğraflarda ilgi görmektedir.

\section{Broken Hill}

Broken Hill, Avustralya'nın güney kısmında Yeni Güney Galler eyaleti ile Güney Avustralya eyaleti sınırında yer almaktadır. Maden yataklarının keşfi sonrasında kurulan Broken Hill, zengin gümüş, kurşun ve çinko maden yataklarına sahiptir. Avustralya'nın önemli limanlarından olan Adelaide yakın olması ve zengin maden yatakları sayesinde bölge kısa sürede yerleşim merkezi haline gelmiştir. Coğrafi olarak engebeli bir yapıya sahip olan Broken Hill, çöl iklimi olduğundan kıraç bir yapıya sahiptir.

Ondokuzuncu yüzyılda Avrupa'dan birçok insan Avustralya'nın kıraç topraklarında maden keşfetme hayaliyle göç etmişti. Avustralya'nın bakir topraklarında yer altı kaynaklarının keşfiyle kısa sürede zengin bir yaşama ulaşmak için onlarca insan bu kıraç topraklara akın etmişlerdi. Bu isimlerden birisi de Charles Rasp't1. 7 Ekim 1846 tarihinde Stuttgart'ta dünyaya gelen Rasp, 1883 Eylül'ünde Broken Hill bölgesinde gümüş, kurşun ve çinko yataklarını keşfetmesiyle hem bölgenin hem de kendi kaderini değiştirmişti. Madenlerin bulunmasıyla Broken Hill bir yerleşim merkezi haline gelmişti. Broken Hill, 1888 yılında belediye, 1907 yılında ise il olmuştu. Broken Hill’in

12 The Sydney Gazette and New South Wales Advertiser, "Death of Admiral Lord Viscount Nelson", 3 Ağustos 1806, s. 2.

13 Sinan Kiyanç, "Qut-Al Amara Victory in the Australian Press." On the 100th Anniversary International Symposium on Baghdad (Madinat Al-Salam) and Qut-Al Amara, 20-22 December 2017. Istanbul: Turkish Historical Society. 
1889 yılında nüfusu 17.000 iken 1915 yılına gelindiğinde bu sayı iki katını aşmış ve 35.000 kişilik bir şehir haline gelmişti. ${ }^{14}$

Broken Hill, Avustralya'daki birçok maden bölgesi gibi Afganistan ve Hindistan'dan gelen devecilerinde önemli yerleşim yerlerinden birisi olmuştur. Avustralya'nın kıraç ve engebeli coğrafyasında ulaşımın sağlanması için develer büyük önem taşımaktaydı. Bölge de sepoy olarak adlandırılan bu insanlar Ghantown denilen mahallelerde yaşamaktaydılar. Böylece Broken Hill kısa sürede farklı dillerin ve dinlerin yaşadığı bir yer haline gelmişti. Charles Rasp'ın öncülüğünde Broken Hill Proprietary BHP şirketi kurulmuştu. BHP'nin yanı sıra küçük ölçekli birçok maden şirketi kurulmuştu. BHP şirketi 1915 yılına gelindiğinde Birinci Dünya Savaşı yıllarında demir ve çelik ihtiyacının büyük kısmını karşılamaktaydı. ${ }^{15}$

Birinci Dünya Savaşı'nın patlak vermesiyle Avustralya'da o güne kadar Almanya'ya ticaret yapan maden şirketlerinin anlaşmalarının feshedilmesiyle maden şirketlerinin büyük kısmı iflas etmişti. Bu şirketlerin iflas etmesiyle büyük bir işsizlik meydana gelmişti. Durum büyük tepki çekmiş ve basında bu durumla ilgili eleştirel yazılar kaleme alınmıştı. ${ }^{16}$

\section{Avustralya'nın Birinci Dünya Savaşı'na Katılışı}

Avustralya, Birinci Dünya Savaşı'na kadar birçok dilden ve dinden insan barındırmaktaydı. Avrupa'dan bu ada ülkesine yer altı zenginliklerini keşfetmek için birçok maceracı göç etmişti. Bunun yanı sıra bölgede birçok ülkeden şirket ticari faaliyetler sürdürmüştü. Böylece Avustralya gerek ticaret gerekse sosyal açıdan önemli bir zenginlik barındırmaktaydı. Avusturalya'da yıllarıdır varlığını gösteren bu insanların Avrupa'daki yurttaşlarının başlattığı savaş kısa sürede dünyanın tamamına yayılmıştı. İngiltere, böylesine bir savaşta sömürgesindeki ülkelerden asker sağlamaya çalışmıştır. İngiltere'nin 4 Ağustos 1914'te Almanya'ya savaş ilan etmesi sonrasında Avustralya'da savaşa girmişti. Avustralya, kilometrelerce uzaktaki savaşa katılma konusunda büyük direnç göstermişti. Her ne kadar İngiltere'nin sömürgesindeki ülkelere karşı başlattığı yoğun propaganda faaliyetlerine karşın savaşa katılım istenildiği gibi olmamıştı. Bu durum savaş yanlısı

\footnotetext{
${ }^{14}$ Peter Spearritt, Where History Happened: The Hidden Past of Australia's Towns and Places, Canberra, National Library of Australia, 2018, s. 37-38.

${ }^{15}$ Ertur, a.g.e., s. 58-59.

${ }^{16}$ Barrier Miner, "How The Commonwealth And State Government Can Provide Ample Work And Wages For Every Man In Australia", 6 Ağustos 1914, s. 2.
} 
Avustralya Hükümetinin ve İngiltere'nin baskısı gittikçe artmasına neden olmuştur. $^{17}$

İngiltere'nin propagandaları ve İngiltere yanlısı hükümetlerin baskıları neticesinde Avustralya, İngiltere ordusunda savaşmak için asker göndermişti. Bunun yanı sıra s1k s1k yapılan yardım kampanyalarına da toplum sessiz kalmamıştır. Savaş yıllarında Avustralya nüfusu 4.9 milyona ulaşmıştı. Birinci Dünya Savaşında Avustralya'dan 416.809 kiși katılırken bu rakam 1844 aras1 erkek nüfusunun \% 38,7 oluşturmuştu. ${ }^{18}$ Avustralya'da savaşın bilançosu son derece ağır olmuştur. Birçok cephede İngiltere yanında savaşta yer alan Avustralyalı askerlerden 4 Ağustos 1914-11 Kasım 1918 tarihleri arasında 59.357 kişi hayatını kaybetmiştir. Roll of Honor kaynakları 31 Mart 1921 tarihinde AIF (The First Australian Imperial Force) son bulmasına kadar bu sayıyı 61.599 olarak belirtmiştir. ${ }^{19}$ Avustralya'nın Birinci Dünya Savaşı'na katılımı yıllara (bk. Tablo 1) ve eyaletlere (bk. Tablo 2) göre dağılımı aşağıda verilmektedir.

Tablo 1. Birinci Dünya Savaşı'na Katılan Avustralyalı Askerlerin Yıllara Göre Dağılımı

\begin{tabular}{lc}
\hline \multicolumn{1}{l}{ Yıl } & Asker Sayısı \\
\hline 1914 & 52.561 \\
\hline 1915 & 165.912 \\
\hline 1916 & 124.352 \\
\hline 1917 & 45.101 \\
\hline 1918 & 28.883 \\
\hline \multicolumn{1}{l}{ Toplam } & 416.809 \\
\hline Kaynak: A. G. Butler, Special Problems and Services: The Official History of The \\
$\begin{array}{l}\text { Australian Army Medical Services in the War of 1914-1918. Canberra, Australian War } \\
\text { Memorial, 1943, s. } 889\end{array}$ \\
\hline
\end{tabular}

${ }^{17}$ Beaumont, a.g.e., s. 45.

${ }^{18}$ Ernest Scott, Australia During The War, The Official History of Australia in the War of 19141918, Sydney, Angus and Robertson Publishing, 1941, s. 889.

19 Roll of Honor, Roll of Honour Database, https://www.awm.gov.au/advancedsearch/people?roll $=$ Roll $\% 20$ of $\% 20$ Honour\&facet_related_conflict_sort $=8 \% 3 \mathrm{AFirst} \% 20 \mathrm{~W}$ orld\%20War\%2C\%201914-1918. 
Tablo 2. Birinci Dünya Savaşı'na Katılan Avustralyalı Askerlerin Eyaletlere Göre Dağılımı

\begin{tabular}{ll}
\hline Eyalet & Asker Sayıs \\
\hline Queensland & 57.705 \\
\hline Yeni Güney Galler & 164.030 \\
\hline Viktorya & 112.399 \\
\hline Güney Avustralya & 34.959 \\
\hline Batı Avustralya & 32.231 \\
\hline Tasmanya & 15.485 \\
\hline Toplam & 416.809 \\
\hline Kaynak: Scott, a.g.e., s. 874. & \\
\hline
\end{tabular}

Birinci Dünya Savaşı'nın hemen başında kurulan İngiltere'nin propaganda ofisi Wellington House, sömürge altındaki ülkelere karşı yoğun bir propaganda faaliyeti yürümüştür. Böylece Avrupa'daki gelişmelerden uzak bir hayat sürmeye çalışan Avustralya savaşın içine çekilmişti. Avustralya'da tüm propaganda faaliyetlerine karşın 1914 y1lında savaşa katılan sayısı 52.561 kişi olmuştur. Avustralya'nın savaşa bakışının değişiminde Broken Hill Saldırısı önemli bir rol oynamıştır. Kilometrelerce uzakta olağan bir şekilde hayatlarına devam eden Avustralyalılar için böylesine bir saldırı endişe ve korkuya neden olmuştu. Broken Hill Saldırısı başsavcısı Billy Hughes'in olaydan birkaç ay sonra başbakanlık koltuğuna oturmuştu. Billy Hughes' in başbakan olması sonrasında Broken Hill Saldırısı, Düşman-Türk olgusunun kullanılmasında önemli bir rol oynamıştır. Billy Hughes'in savaş karşıtlarına karşı kullanmaktan çekinmediği Broken Hill Saldırısı, toplumun savaşa bakışında Çanakkale Savaşı öncesindeki en önemli olaydir. ${ }^{20}$

Birinci Dünya Savaşı yıllarında Avustralya'da önemli yardım kampanyaları da hayata geçirilmişti. Bu yardım kampanyaları kapsamında cephedeki askerler için gerek giyecek gerekse diğer ihtiyaçlarını karşılanması sağlanmıştır. Böylece Birinci Dünya Savaşı Avustralya'da kapsamlı bir şekilde hissedilmişti. Bunun yanı sıra savaş sürecinde oluşturulan fona para yardımları da sağlanmıştır. Bu kampanyalar sürecinde Broken Hill'in bağlı olduğu Yeni Güney Galler eyaleti ilk sırada yer almıştır. ${ }^{21}$ Avustralya'da Birinci Dünya Savaşı yıllarında asker katılımının azalması üzerine zorunlu askerlik sisteminin getirilmesi için iki tane referandum yapılmıştır. Avustralya'da 28 Ekim 1916 ve 20 Aralık 1917 tarihlerinde yapılan

20 Scott, a.g.e., s. 111-112.

21 A.g.e., s. 698 ve 737. 
referandumda hayır oyu çıkmıştır. Yeni Güney Galler eyaleti referandum sonuçlarında da açık farkla hayır çıkmıştır. ${ }^{22}$

\section{Broken Hill Saldırısı'nın Düzenlenmesi}

Broken Hill'de Manchester Unity Order of Oddfellows Club tarafindan Silverton'da düzenlenen geleneksel pikniğe katılmak için 1 Ocak 1915 tarihinde 1.200 kişi açık vagonlardan oluşan trenle saat 10.00'da Silverton'a doğru hareket etmişti. Trenin Broken Hill istasyonundan ayrılmasından yaklaşık on dakika sonra saldırıya uğramıştı. Yolun kenarında bulunan bölgenin bitki örtüsü olan- fundalık arasından yirmi ila otuz el ateş edilmişti. Saldırı sonrasında trende büyük panik yaşanmıştı. Olayda yaralılara yardım etmek için tren Broken Hill istasyonuna geri dönmüştü. Görgü tanıklarına göre saldırının yapıldığ 1 yerde Gül Muhammed'e ait olan dondurma arabası ve üzerinde Osmanlı İmparatorluğu bayrağı bulunmaktaydı. Görgü tanıkları saldırıyı gerçekleştirenlerin iki kişi olduklarını belirtmişlerse de yüzlerinin kapalı olduğundan kim oldukları tespit edilememişti. Ancak Gül Muhammed'e ait dondurma arabasının kullanılması saldırının bu isim tarafından yapıldığını iddiasıyla bu isim aranmaya başlamıştı. Saldırı sonrasında Broken Hill'de büyük panik yaşanmıştı. Saldırganların beyaz kayalara (White Rocks) gittikleri haberi alınınca Broken Hill'de görevli polisler beraberindeki silahlı milis kuvvetlerle saldırganların bulunduğu yere gitmişlerdir. Beyaz kayalarda sıkıştırılan iki saldırgan ile çıkan çatışma saldırganların beyaz bayrak çekmelerine karşın çatışma devam etmişti. Çıkan çatışma da Molla Abdullah olay yerinde hayatını kaybetmiş, Gül Muhammed ise ağır yaralı olarak ele geçirilmişti. Gül Muhammed kaldırıldığı hastanede hayatını kaybetmişti. Saldırganların cenazelerinin kimse tarafından kabul edilmemesi üzerine polis tarafindan gizli bir şekilde gömülmüştü. ${ }^{23}$

Saldırganların kullandıkları Martini-Henry Tüfek, bir adet Snider-Enfield filinta ve bir adet kırk dört kalibreli Smith-Wesson silahları bulunmuştu. Saldırı sonrasında çekilen fotoğraflara göre saldırganların mermilerinin bir kısmının kullanılmadığı açıktır. Bunun yanı sıra Molla Abdullah'ın evinde yapılan araştırma da bir adet Kuranı Kerim ve içinde Osmanlı Sultanından geldiği iddia edilen mektup bulunmuştu. Saldırganlar hakkında dikkat çeken bir nokta ise saldırganların uyuşturucu madde kullandığıyd ${ }^{24}$

Broken Hill Saldırısı sonucunda dört kişi hayatını kaybetmiş, yedi kişi yaralanmıştı. Saldırıda Elma M. Cowie ve William Shaw trende, A. E. Millard

22 A.g.e., s. 352 ve 427.

23 Barrier Miner, "War in Broken Hill", 1 Ocak 1915, s. 2; Ertur, a.g.e., ss. 142-164.

24 A.g.e., s. 204-205. 
bisikletiyle treni takip ederken, James Greig evinin bahçesinde odun kırdığı sırada çatışmadan seken kurşunla hayatını kaybetmişti. Saldırı da hayatını kaybeden William Shaw piknik organizasyonunu düzenleyen papazdi. Bölgede son derece saygı durulan William Shaw'ın hayatını kaybetmesi neticesinde Hıristiyan din adamının Müslümanlar tarafından öldürüldügüü imajı toplumun tepkisini artırmıştı. Saldırı da yaralananların isimleri şöyledir: Mary Kavanagh, George F. Stokes (14-15 yaşlarında), Thomas Campell, Lucy Shaw (15 yaşında), Alma Croker, Beyrl Lane, Rose Crabb'dır. Thomas Campell'in dışında tüm isimler trende bulunuyorlardı. Thomas Campell saldırganların beyaz kayalara doğru kaçarken saldırganların açtığı ateş ile yaralanmıştı. ${ }^{25}$

Broken Hill'de akşam saatlerinde öfkeli kalabalık toplanmıştı. O güne kadar Broken Hill'de faaliyet gösteren Almanlara ve Müslümanlara karşı herhangi bir saldırı gözlenmemişti. Ancak birkaç bin kişilik öfkeli kalabalık Delamore Caddesinde bulunan Alman kulübüne yürümüş ve kulübü ateşe vermişlerdi. Alman kulübünü ateşe veren kalabalık bu kez yönünü Ghantown'a çevirmişti. Afgan ve Hintli devecilerin yaşadığı mahallede öfkeli kalabalıktan nasibini almıştı. ${ }^{26}$

Broken Hill Saldırısı o güne kadar şehirde beraber yaşayan toplulukların ayrışmasına neden olmuştu. New South Wales Migration Heritage Centre kayıtlarına göre saldırı sonrasında Broken Hill'de meydana gelen olaylar neticesinde Alman, Avusturyalı ve Türkler düşman yabancılar olarak ilan edilmişti. Bunun üzerine Broken Hill'de bulunan altı Avustralyalı, dört Alman ve bir Türk polis tarafindan kayıt altına alınarak 1914 yılında çıkarılan Ingiliz Milletler Topluluğu Savaş Önlemleri Yasası kapsamında Birinci Dünya Savaşı'nın sonuna kadar Holsworty Toplama Kampı'na gönderilmişlerdi. ${ }^{27}$ Broken Hill Saldırısı sonrasında tepkiler bununla kalmamıştı. Hükümet durumu Düşman-Türk olgusu üzerinden etkili bir propaganda olarak kullanmıştı. Hükümet üyeleri tarafından olay kınanmıştı. Savunma Bakanı ülke de düşman yabancıların kalmaması konusunda etkin bir mücadele vereceklerini belirtmişti. Broken Hill'de yaşanan tepkiler kısa sürede diğer kesimlere de sıçramıştı. Adelaide'de bulunan Avustralya'daki ilk camiye

${ }^{25}$ Kalgoorlie Miner, "The Broken Hill Outrage", 4 Ocak 1915, s. 4.

${ }^{26}$ The Register, "Speedy Revenge", 2 Ocak 1915, s. 9.

${ }^{27}$ NSW Migration Heritage Centre, The Enemy At Home, German Internees in World War I Australia, http://www.migrationheritage.nsw.gov.au/exhibition/enemyathome/battle-ofbroken-hill/index.html. 
saldırı düzenlenmişti. Tepkinin bir neticesi olarak Avustarlya' da Germantown gibi yer isimleri Holbrook ve Grovedale olarak değiștirildi. ${ }^{28}$

\section{Borken Hill Saldırısı'nın Basına Yansıması}

Broken Hill Saldırısı konusunda en iyi kaynak olan Avustralya Basın Arşivi'nde yer alan gazetelerde olay sonrasında tutumda farklilıklar bulunmaktadır. Olay basında geniş bir yer tutmuştur. Ancak olayın aktarılmasında farklılıklar bulunmaktadır. Saldırıyı gerçekleştirenlerin Türk oldukları ile ilgili basında geniş bir yargı oluşmuştu. Bunun temel nedeni saldırı anında kullanılan bayraktı. Osmanlı İmparatorluğu bayrağı nedeniyle saldırganların Türk oldukları hakkında genel bir kanı oluşmuştur. ${ }^{29}$

Avustralya basınında Broken Hill Saldırısı konusunda Düşman-Türk olgusundaki katı tutumunun aksine tutum takınan gazetelerde bulunmaktaydı. $\mathrm{Bu}$ gazeteler saldırının Türkler tarafından değil, Hintliler tarafından yapıldığını belirtmişti. Buna örnek olarak olayın hemen sonrasında 2 Ocak 1915 tarihli The Border Morning Mail and Riverine Times gazetesi Hintliler Trene Ateş Açtı, Üç Kişi Hayatını Kaybetti, Sekiz Kişi Yaralandı, İki Saldırgan Öldürüldü̈ başlığgyla vermiştir. ${ }^{30}$

Basında yer alan haberlerde saldırganların Türk olduğu haberleri ve toplumsal tepki karşısında Avustralya Osmanlı Birliği Başkanı S. J. Attiah saldırıdan bir gün sonra yaptığı açıklamada saldırganların Türk olduğu ile ilgili çıkan haberlere tepki göstermiştir. S. J. Attiah, Osmanlı İmparatorluğu'nun böylesine bir olayla ilişkilendirilmesine karşı çıkmıştır. Saldırganların Osmanlı İmparatorluğu adına gerçekleştirildiği iddialarının doğruyu yansıtmadığını belirtmiştir. Saldırının İngiltere'nin egemenliğindeki ülkelerden Avustralya'ya göç eden Afganlar tarafından gerçekleştirildiğini vurgulayan S. J. Attiah, böylesine acı bir olayın üzüntüsünü ve saldırganların Türk oldukları iddiası karşısında kaygısını belirten şu açıklamayı yapmıştı:: ${ }^{31}$

"Türklerin bu işte saldırgan olduğu ifadesini anlayamıyorum. Broken Hill'de veya Avustralya'nın herhangi bir yerinde saf Türk yoktur. Çok sayıda Osmanl tebaasl var ancak bunlar Avrupa güçlerinin tehlikesi altındaki Lübnan'in dağllk kesimlerindendir. Bu olayla ilgilenen saldirganlar,

28 Damien Murphy, "Broken Hill, New Year's Day, 1915 was Australia's First Terrorist Attack", https://www.smh.com.au/national/nsw/broken-hill-new-years-day-1915-wasaustralias-first-terrorist-attack-20141014-115weh.html.

29 The Argus, "Turks Attack Train", 2 Ocak 1915, s. 9.

30 The Border Morning Mail and Riverina Times, "Indians Fire at Train, Three People Killed and Eight Wounded, Two Murdered Dead", 02 Ocak 1915, s. 2.

31 The Register, "Assailants Not Turks, Denial By Prominent Ottoman”, 2 Ocak 1915, s. 9; Daily Herald, "Not Ottomans", 2 Ocak 1915, s. 4. 
inanıyorum ki, fanatizm tarafindan harekete geçirilen Müslüman Afganlardı ve kesinlikle Osmanl tebaası değillerdi. Saldırganlar İngiliz Devletler Topluluğundan olduğu çok iyi bilinmektedir ve böyle çılgın bir öfkeden (Osmanl Imparatorluğu) hiçbir şekilde sorumlu değildir. Saldırganlar, Türkiye'ye sadakatten değil, fanatizmden etkilenmiş olmalılar. Bu insanların Türk olduğunu söylemek bir hatadır ve kamuoyuna böyle söylenmesi gerekir.

Avustralya'daki Osmanlı Birliği Başkanı S. J. Attiah, saldırı sonrasında Broken Hill'i ziyaret etmiş ve yetkililerle görüşmüştür. Bu ziyaret kapsamında verdiği röportaj saldırının aydınlatılması için son derece önemlidir. S. J. Attiah röportajında Osmanlı İmparatorluğu'nu belirterek, Türk ifadesinin Osmanlı İmparatorluğu'nu kapsamadığını belirterek, Osmanlı İmparatorluğu'nun çok milletli bir yapıya sahip olduğunu vurgulamıştır. Kendisinin de Suriye'de doğduğunu ve sonrasında eğitim için Mısır'a gittiğini burada askeri eğitim aldığını ifade etmiştir. Basında saldırı sonrasında çıkan haberlere bir kez daha tepki gösteren S. J. Attiah bu olayın Osmanlı İmparatorluğu ile ilişkilendirilmesine karşı çıkmıştır: ${ }^{32}$

S. J. Attiah'ın bu mücadelesine karşın saldırının Düşman-Türk olgusu üzerinden sürdürülmüştür. Öyle ki S. J. Attiah'ın açıklamaları basında yer bulması üzerine Molla Abdullah'ın Teşkilatı Mahsusa ile bağlantılı olduğu iddiası ortaya atılmıştır. Molla Abdullah, Teşkilatı Mahsusa üyesi olduğu iddiasının yanı sira, Avustralya'da bulunan Afganların saldırıy gerçekleştirenlerin Afgan olmadıklarını, Türk olduklarını belirten haberler basında yer bulmuştur. Basında Düşman-Türk olgusu üzerinden tahrik edici manşetler atılmıştır. ${ }^{33}$

\section{Molla Abdullah ve Gül Muhammed}

Molla Abdullah 1855 yılında Hindistan'ın Afganistan sınırında dünyaya gelmiştir. Afganistan'da kullanılan yerel dilini konuşmaktaydı. Medrese eğitimi görmüş ve muhtemelen Molla sınıfindan bir aileden geldiğinden ötürü babadan oğula geçen Molla lakabını kullanmıştı. Molla Abdullah 1890 yılında Güney Avustralya'ya gelmiş, 1899 yılından itibaren Broken Hill'de yaşamıştır. Broken Hill'de Afganların yaşadığ 1 Ghantown'a yerleşmiş, burada imamlık yapmıştır. Molla Abdullah saldırıyı düzenlediğinde 60 yaşındaydı. Molla Abdullah imamlığının yanı sıra bölgede yaşayan Müslümanlar için İslami usullere göre kasaplık görevini de üstlenmişti. Saldırı sonrasında

32 Barrier Miner, "Mr. Attiah Interviewed", 31 Ocak 1915, s. 1.

33 Barrier Miner, "Mullah Abdullah's Nationality", “An Afghan's Disclaimer”, 7 Ocak 1915, s. 2; The Sydney Morning Herald, "The Fight With The Turks", 4 Ocak 1915, s. 10. 
yapılan soruşturma da Ghantown'da Molla Abdullah ile beraber yaşayan insanlar onun gayet sessiz ve kendi halinde birisi olduğu belirtilmiştir. Çok az konuşan ve kendi halinde birisi olarak tasvir edilmiştir. Avustralya'da yaşadığı süre zarfında herhangi bir asayiş olayına karışmayan Molla Abdullah, kasaplık yaptığından ülkedeki havyan kesimi konusundaki kanunlara uymadığ 1 gerekçesiyle saldırıdan kısa bir süre önce para cezası almış, bu cezasını ödeyememişti. Kamptakiler Molla Abdullah'ın herhangi bir silaha sahip olmadığını da belirtmişlerdi.

Gül Muhammed ise 1875 yılında Osmanlı İmparatorluğu'na yakın bir bölgede yani İran sınırına ya da Hindistan'ın kuzey doğu sınırına yakın bir yerde doğduğu ifade edilmiştir. Avustralya'ya ve Broken Hill'e ne zaman geldiği belli olmasa da Broken Hill'e geldikten sonra kamptan ayrılmıştı. Kamptakilerin ifadesine göre dünyayı gezmişti. Saldırıdan kısa bir süre önce kampa gelerek Molla Abdullah'ın yanında yaşamaya başlamıştır. İkisi hakkında dikkat çeken bir iddia ise sık sık Hint keneviri içtikleridir. İddia edildiğine göre Gül Muhammed Osmanlı İmparatorluğu için savaştıktan sonra 1912 yılında Avustralya'ya dönmüştü. Bir süre gümüş madenlerinde çalıştıktan sonra dondurma satmaya başlamıştır. ${ }^{34}$

Saldırı sonrasında başlatılan soruşturma da basına yansıyan kesiminden Molla Abdullah ve Gül Muhammed'in karakterleri ve yaşam biçimleri hakkında bilgilere ulaşılabilmektedir. Molla Abdullah'ın çevresi tarafından sevilen ve sayılan bir insan olduğu ifade edilmiştir. Ghantown'daki mescitte 16 yıldır imamlık yapmasının yanı sıra mahalledeki Müslüman ahali için kasaplık yapmıştır. Son derece sessiz olan Molla Abdullah herhangi bir asayiş olayına da karışmamıştır. Kampta yaşayanların Afgan olarak isimlendirmelerine karşı burada yaşayanların İngiltere egemenliğindeki Hindistan'dan göç etmişlerdi. Soruşturma kapsamında elde edilen bir başka bilgi ise Ghantown'da yaşayanların Müslüman olmalarına karşın İngiltere'ye son derece sadık olduklarıdır. Kampta bulunan bazı isimlerin İngiltere'nin yanında Hindistan ordusuna katılmak için kamptan ayrıldıklarına hatta bazılarının polise başvurarak Avustralya ordusuna katılmak istedikleri belirtilmiştir. Ghantown'da yaşayanların İngiltere'ye son derece sadık olmalarına karşın onlara yıllardır imamlık yapan Molla Abdullah, hiç kimseye haber vermeden cihat çağrısı neticesinde böylesine bir saldırı yapması dikkat çeken bir ayrıntıdır. ${ }^{35}$

34 Pamela Rajkowski, In The Tracks of The Camelmen: Outback Australia's Most Exotic Pioneers, North Ryde, N.S.W., Angus \& Robertson Pub., 1987, s. 126; Christine Stevens, Tin Mosque \& Ghantowns: A History of Afghan Cameldrivers in Australia, Melbourne, Oxford University Press., 1989, ss. 164-166.

${ }^{35}$ Barrier Miner, "The New Year's Day Massacre", 02 Ocak 1915, s. 4. 
The Evening Echo gazetesinin soruşturma sonrasında yaptığ ismin çok sakin görünmelerine karşın saldırıyı gerçekleştiren isimlerden Molla Abdullah'1, (1srarla Türk olduğu iddia edilmiş) Gül Muhammed etkilediği iddia edilmiştir. Gül Muhammed'in Osmanlı İmparatorluğu ile savaşta olan İngiltere İmparatorluğu'na karşı düşmanca bir tavır içine girdiğini ve bu nedenle böylesine bir eylemi gerçekleştirmek için ikna ettiğini ifade etmiştir. Bunun yanı sıra Savunma Bakanı soruşturmanın yapıldığını ve İngiltere düşmanlarına izin verilmeyeceğini ifade etmiştir. Gül Muhammed ve Molla Abdullah'ın biyografisinde belirtildiğine göre Molla Abdullah'ın Ghantown'da imamlık yapmasının yanı sıra devecilerin lideridir. Kampta yaşayanların bir kısmının İngiltere adına Hint ordusuna katılmak için kamptan ayrılmış hatta bazıları ise Avustralya ordusuna katılmak için başvurmuştur. Dini önder olan Molla Abdullah ise bunlardan ayrı olarak böylesine bir saldırı yapması kamptaki konumu karşısında saldırı konusunda şüpheleri ortaya koymaktadır. $^{36}$

Daily Herald gazetesi saldırganları Türk olarak ifade etmesinin yanı sıra bir adım daha ileri giderek saldırganların eski Türk askeri olduklarını iddia etmişti. Molla Abdullah'ın bu vazifeyi dört kez yaptığını belirtilmişti. ${ }^{37}$

\section{İntihar Mektupları}

Broken Hill Saldırısı sonrasında tepkilerin yanı sıra saldırının neden yapıldığı kamuoyu tarafindan en çok merak edilen soruydu. $O$ güne kadar yaşadığı topraklarda kendi haline iki insanın böylesine bir saldırıyı yapmaları ayrı bir tartışma unsuru olmuştu. Saldırganların öldürüldüğü yer olan Beyaz Kayalar da çatışmadan üç gün sonra yapılan inceleme de kayaların arasında iki mektup bulunmuştur. Kamuoyuna intihar mektupları olarak duyurulan mektuplar Urduca dilinde Arap harfleriyle yazıldığından İngilizce tercüme sonrasında yayınlanmıştır. Mektuplar düzgün bir el yazısıyla yazıldı̆̆ 1 dikkat çekmektedir. Mektupların sonunda Gül Badşa Muhammed Afridi ve Molla Abdullah isimleri yazılmıştır. ${ }^{38}$ İlk mektup Gül Muhammed'e ikinci mektup ise Molla Abdullah'a ait olduğu belirtilmiştir. ${ }^{39}$

Gül Muhammed'e ait olduğu iddia edilen mektup:

36 The Evening Echo, "Broken Hill Outrage", 04 Ocak 1915, s. 2.

37 Daily Herald, "The Barrier Outrage, An Ex-Turkish Soldier", 07 Ocak 1915, s. 3.

38 The Advertiser claims that the letters were written in two different handwritten letters during a meeting with the authorities in the letter. However, it was claimed that the letters were written by Mullah Abdullah with the same writing. The Advertiser, "Fight Only For The Sultan", 13 Ocak 1915, s. 8.

39 The Age, "Broken Hill Outrage", 06 Ocak 1915, s. 11; Daily Telegraph, "Extraordinary Documents Discovered", 06 Ocak 1915, s. 6. 
"Ben fakir bir adamım ve Sultan Hamid'in (II. Abdülhamid) ülkesine aitim. Dört kez Türkiye'ye gittim. Savaşmak istiyorum. Orada savaşma şansım olmadl. Abdul Hamid mühürlü bir mektup gönderdi. Mücadele ederken yeleğime bağlarım, halkını öldürürüm, çünkü halkın ülkemle savaşıyor. ... Hiçbir düşmanım yok, kimse bana bunu yapmamı söylemedi ve kimseye söylemedim. Allah şahidim olsun ikimiz dışında kimse bilmiyor."

Molla Abdullah'a ait olduğu iddia edilen mektup:

"Ben fakir bir adamım ve fakir bir günahkârım. Sadece ikimiz ne yaptığımızı biliyoruz. Bir gün çok endişelendim çünkü mahkemeye çağrıldım. Beni affetmelerini istedim ama yapmadılar ve bunun için endişelendim ve çok üzüldüm. Düşünürken Gül Muhammed bana geldi ve ne düşündüğümü söyledim. Bana benden büyük olan dertlerini söylediğinde, kalbimi rahatlattı. Sonra ikimiz de Allah'a dua ettik. Mahkeme dışında hiçbir erkek bize müdahale etmedi ve uzun zaman önce türban taktığım için çocukların bazılarının taş attı. Bundan hoşlanmadım ve bugün bu yüzden türban taktım. Çocukların taş attığı günden beridir bir daha türban takmadım. Bugün türban taktım. Yaptığımızı Allah'tan başka hiç kimse bilmemektedir. Bunun doğru olduğuna yemin ederim."

Gül Muhammed'in ifadelerinde belirttiği ve II. Abdülhamid'den (1909 y1lında II. Abdülhamid tahttan indirilmiştir) gelen mektubunda polisin ele geçirdiği belirtilmiştir. ${ }^{40}$ II. Abdülhamid'den geldiği iddia edilen mektup araştırmalarda elde edilememiştir. Mektupların kamuoyuna açıklanması üzerine çıkan haberlerde Gül Muhammed'in ifadelerinin yer aldığı mektuptaki ifadelere dayanılarak Sadece Sultan Iç̧in Savaşırım başlıklı haberler yapılmıştır. ${ }^{41}$

Mektuplar incelendiğinde saldırı ile ilgili şüpheleri artırmaktadır. Saldırı sonrasında yapılan tüm incelemelere karşın saldırganların ait başka belge ya da ipucu bulunmadığı için mektupların karşılaştırılabileceği yazılı bir kaynak bulunmamaktadır. Bunun yanı sira saldırganlara ait oldukları iddia edilen mektuplar incelendiğinde yazıların gayet düzgün bir el yazısıyla yazıldığı görülmektedir. Bir başka dikkat çeken iddia ise ise Gül Muhammed'in Osmanlı İmparatorluğu için dört kez savaştığıdır. Oysa Osmanlı İmparatorluğu Savaş Tarihine bakıldığında saldırı günü 40 yaşında olan birisinin savaşacağı sadece Balkan Harbi bulunmaktadır. Bir başka dikkat çeken nokta ise Birinci Dünya Savaşı nedeniyle cihadın II. Abdülhamid tarafından ilan edildiği belirtilmiştir. Oysa II. Abdülhamid 31 Mart olayı

${ }^{40}$ Kerang New Times, "Broken Hill Tragedy, Turks Last Letters", 08 Ocak 1915, s. 2.

${ }^{41}$ The Express and Telegraph, "Fight Only For The Sultan", 13 Ocak 1915, s. 4. 
sonrasında 29 Nisan 1909 tarihi itibariyle tahtan indirilerek yerine Mehmet Reşat geçmiştir.

Broken Hill Saldırısı sonrasında yapılan kapsamlı soruşturma sonrasında elde edilen mektuplarda tutarsızlıklar göze çarpmaktadır. Bu tutarsızlıklar, saldırının Birinci Dünya Savaşı çerçevesinde bir propaganda haline gelmesi nedeniyle üzerinde durulmamıştır. Ancak soruşturma sürdüğü günlerde Avusturalya Osmanlı Birliği Başkanı S. J. Attiah tarafından açık bir şekilde ortaya konulmuştur. S. J. Attiah mektuplarda dikkat çeken tarihsel hataya vurgu yaparak II. Abdülhamid'in tahtan indirildiğine ve yerine Mehmet Reşat'ın geçtiğini belirtse de bu durum Attiah'ın diğer açıklamaları gibi bazı bazın organları tarafından kaleme alınsa da görmezden gelinmiştir (S. J. Attiah'ın olayın hemen sonrasında yaptığı açıklamada soruşturma da elde edilen bulgulardaki hatalara dikkat çekmiştir. Attiah yaptığı açıklamada II. Abdülhamid'in 1908 tarihinde tahttan indirildiğini belirtmiştir. Oysa II. Abdülhamid, 1909 yılında tahtan indirilmiştir. ${ }^{42}$

\section{Sonuç}

Avustralya'nın güneyinde yer alan Broken Hill'de Birinci Dünya Savaşı'nın hemen başında meydana gelen saldırı Avustralya tarihindeki ilk terör saldırısıdır. Bu nedenle Avustralya tarihinde önemli bir yer tutmaktadır. Broken Hill Saldırısı hakkında günümüze kadar birçok alanda konu olmuştur. Bu çalışmaların genelinde Birinci Dünya Savaşı'nın hemen başında Osmanlı İmparatorluğu tarafından cihat ilan edilmesi üzerine Türklerin savunmasız sivillerden oluşan trene saldırdığ 1 olgusuyla yer etmiştir. Broken Hill'de meydana gelen saldırı ülkede önemli bir tepkiye neden olurken, Birinci Dünya Savaşı'na gönüllü asker olarak katılımı da artırmıştır.

Birinci Dünya Savaşı'nın hemen başında Düşman-Türk olgusunun oluşmasında son derece etkili olan Broken Hill Saldırısı'ndan İki Türk sorumlu tutulmuştur. Oysa daha saldırının yapıldığı günlerde Avustralya Osmanlı Birliği Başkanı S. J. Attiah'ın çabaları basında yer bulsa da bu imajı yıkmaya yeterli olmamıştır. Saldırıdan yıllar sonra bile saldırının iki Türk tarafından yapıldığı olgusu korunmuştur. Avustralya'da kısa sürede etkiye neden olan saldırı Türkiye'de de Kahraman-Türk olgusu üzerinden ele alınmıştır. Avustralya'da iki kahraman Türk tarafından saldırının yapıldığ tıpkı Avustralya'da olduğu gibi Türkiye'de de etkili olmuştur.

Broken Hill Saldırı hakkında aydınlatıcı araştırmaların az olması toplumsal hafiza da propaganda unsuru haliyle yerleşmesine neden olmuştur.

42 The Register, "Not Turks", 8 Ocak 1915, s. 7. 
Saldırı belgelerinin yıllarca ulusal güvenlik nedeniyle kamuoyuna açılmaması saldırı hakkında araştırmaları zorlaştırmıştır. Belgelerin yangından zarar görmesiyle saldırının aydınlatılması iyice zorlaşmıştır. Saldırıdan yüz yıl sonra bile Broken Hill Saldırısı hakkında araştırma yapanların sayısı son derece azdı. Bu nedenle Broken Hill Saldırısı hakkında yazılan eserlerde propaganda unsuru haliyle varlığını korumuştur.

Broken Hill Saldırısı hakkında elimizdeki en iyi kaynak döneme ışık tutan Avustralya Basın Arşivi'dir. Broken Hill Saldırısı basında geniş yer tutmuştur. Basının olaya bakışı farklılıklar barındırmaktadır. Saldırının iki Türk tarafından gerçekleştirildiği iddiasıyla Düşman-Türk imajı etkili olmuştur. Buna karşın saldırının Türkler değil Hint ya da Afganlar tarafından yapıldığ 1 az da olsa basında yer tutmuştur. Ancak bu farklılıklara rağmen Broken Hill Saldırısı'nın Türkler tarafından işlendiği toplumsal hafiza da geniş yer tutmuştur.

Broken Hill Saldırısı'nın Türkler tarafından gerçekleştirilmediği son derece açıktır. Olayın Birinci Dünya Savaşı gölgesinde Türk, dolayısıyla Osmanlı İmparatorluğu üzerine yıkılmaya çalışılmıştır. Bu konuda elde ki en güçlü kanıt saldırı da kullanılan Osmanlı İmparatorluğu bayrağıdır. Bunun yanı sıra saldırıdan üç gün sonra saldırganların öldürüldüğü beyaz kayalarda bulunan iki mektupta belirtilen ifadeler dikkat çekicidir. Mektupların düzgün bir el yazısıyla yazıldığı ortadadır. Mektupların sonuna saldırganlarının ismi son derece açık yazılmış ve imza olarak kabul edilmiştir. Oysa böylesine bir yazıyı kullandığı iddia edilen Molla Abdullah'ın başka bir notuna ulaşılamamıştır. Bunun yanı sıra mektuplarda belirtilen bilgilerde saldırının sadece iki kişi tarafindan gizli olarak yürütüldüğünün vurgusu dikkat çekmektedir. Cihat ilanı neticesinde yapıldığı iddia edilen saldırının, Müslüman bir mahallede on altı yıldır imamlık yapan bir isim tarafindan kimseye tebliğ edilmemesi dikkat çekmektedir. Hele hele bu mahallede bulunanların bir kısmının İngiltere İmparatorluğu yanında savaşta yer alan Hint ordusuna katılmak için ayrılmıştır. Bunun yanı sıra Avustralya'da Osmanlı İmparatorluğu'na karşı savaşmak için başvuru yapmıştır. Bu durum açıkça göstermektedir ki Broken Hill'de yer alan Ghantown'da cihat ilanının etkisi görülmemiştir.

Broken Hill Saldırısı'nda Gül Muhammed 40, Molla Abdullah 60 yaşındaydı. Soruşturma kapsamında mahallede saldırı büyük şaşkınlıkla karşılanmıştır. Molla Abdullah'1 son derece sessiz ve kendi halinde tanımlayan Ghantown' da yaşayan insanlar iki isminde o güne kadar ateşli bir silah sahip olmadıklarını da belirtmişlerdir. Basın, Molla Abdullah'ın böylesine bir saldırı da bulunmasının asıl nedeninin Gül Muhammed olduğunu iddia etmişlerdi. Gül Muhammed'in Broken Hill'de dondurmacılık 
yapmıştır. Israrla Osmanlı İmparatorluğu'na gittiği ve burada dört kez savaştığ 1 ifade edilmiştir. Oysa Gül Muhammed'in yaşı itibariyle dört savaşa katıldığı kronolojik bir hatanın varlığını göstermektedir. Bunun yanı sıra Gül Muhammed'in Osmanlı İmparatorluğu'na gittiği hakkında herhangi bir ifadeye rastlanmamıştır.

Basında saldırıyı gerçekleştirenleri Osmanlı İmparatorluğu sempatizanı olarak göstermek için yoğun bir çaba gösterildiği açıktır. Bu nedenle saldırının detayları görmezden gelinmiştir. Saldırganların Hint keneviri kullandıkları ve saldırı anında uyuşturucu madde etkisinde olduğu görgü tanıkları tarafından belirtilmiştir. Oysa saldırının yapıldığı yerden, saldırganların öldürüldüğü yer olan beyaz kayalara gitmeleri pek mümkün olmadığından saldırganların aslında kurbanlardan olduğu iddialarını güçlendirmektedir.

Saldırının yapılış şekline bakıldığında o güne kadar böylesine bir saldırı yapılmamıştır. Tamamen sivillerden oluşan ve temsili bir günde yapılan bu saldırının toplumda nefret uyandırması amacıyla kullanılmıştır. Osmanlı İmparatorluğu'nun masum insanlara saldırdığı yalanı üzerinden değerlendirilen saldırı kendi içinde birçok tutarsız noktayı barındırmaktadır.

\section{Kaynakça}

Barrier Miner, "How The Commonwealth And State Government Can Provide Ample Work And Wages For Every Man In Australia", 6 Ağustos 1914.

Barrier Miner, "Mr. Attiah Interviewed", 31 Ocak 1915.

Barrier Miner, “Mullah Abdullah's Nationality”, “An Afghan's Disclaimer”, 7 Ocak 1915.

Barrier Miner, "The New Year's Day Massacre", 02 Ocak 1915.

Barrier Miner, "War in Broken Hill”, 1 Ocak 1915.

Beaumont, Joan, Broken Nation: Australians in the Great War, Sydney, Allen \& Unwin Publishing, 2013.

Bendigo Advertiser, "The Battle Of Broken Hill, German Official Account", 26 Mart 1915.

Daily Herald, “The Barrier Outrage, An Ex-Turkish Soldier”, 07 Ocak 1915.

Daily Herald, "Not Ottomans", 2 Ocak 1915.

Daily Telegraph, "Extraordinary Documents Discovered", 06 Ocak 1915.

Ertur, Ömer, Derin Nefret, Anzakları Çanakkale Savaşı'na Sokan Komplo'nun Hikâyesi, Çeviren: Güneş Ayas, İstanbul, Donkişot Publishing, 2011.

Kalgoorlie Miner, “The Broken Hill Outrage”, 4 Ocak 1915. 
Kerang New Times, "Broken Hill Tragedy, Turks Last Letters", 08 Ocak 1915.

Kıyanç, Sinan, "Qut-Al Amara Victory in the Australian Press." On the 100th Anniversary International Symposium on Baghdad (Madinat Al-Salam) and Qut-Al Amara, 20-22 December 2017. Istanbul: Turkish Historical Society.

McCourt, Chris, The Cleaning of Mahommed, Sydney, Fourth Estate Publishing, 2012.

Murphy, Damien, "Broken Hill, New Year's Day, 1915 was Australia's First Terrorist Attack", https://www.smh.com.au/national/nsw/broken-hill-new-years-day1915-was-australias-first-terrorist-attack-20141014-115weh.html.

NSW Migration Heritage Centre, The Enemy At Home, German Internees in World War I Australia, http://www.migrationheritage.nsw.gov.au/ exhibition/enemyathome/battle-of-broken-hill/index.html.

Rajkowski, Pamela, In The Tracks of The Camelmen: Outback Australia's Most Exotic Pioneers, North Ryde, N.S.W., Angus \& Robertson Pub., 1987.

Roll of Honor, Roll of Honour Database, https://www.awm.gov.au/advancedsearch/people?roll $=$ Roll $\% 20$ of $\% 20$ Honour\&facet related conflict sort $=8 \% 3 \mathrm{~A}$ First\%20World\%20War\%2C\%201914-1918.

Saltık, Ekrem, “1915'de Avustralya'da Bir Terör Sladırısı ‘Kahramanlık’ mı, Komplo mu?", Toplumsal Tarih, 2011, vol. 205, ss. 88-93.

Sanders, Michael L., "Wellington House and British Propaganda During the First World War", The Historical Journal, 1975, vol. 18, ss.119-146.

Scott, Ernest, Australia During The War, The Official History of Australia in the War of 1914-1918, Sydney, Angus and Robertson Publishing, 1941.

Shakespeare, Nicholas, Oddfellows, Vintage Australia, Random House Publishing, 2015.

Spearritt, Peter, Where History Happened: The Hidden Past of Australia's Towns and Places, Canberra, National Library of Australia, 2018.

Stevens, Christine, Tin Mosque \& Ghantowns: A History of Afghan Cameldrivers in Australia, Melbourne, Oxford University Press., 1989.

Şakar, Recep "Broken Hill Saldırısı Komplo mu?" http://www.hurriyet.com.tr/gundem/broken-hill-saldirisi-komplo-mu21951919.

The Advertiser, "Fight Only For The Sultan", 13 Ocak 1915.

The Age, "Broken Hill Outrage", 06 Ocak 1915.

The Argus, "Turks Attack Train”, 2 Ocak 1915. 
The Border Morning Mail and Riverina Times, "Indians Fire at Train, Three People Killed and Eight Wounded, Two Murdered Dead”, 02 Ocak 1915.

The Evening Echo, "Broken Hill Outrage", 04 Ocak 1915.

The Express and Telegraph, "Fight Only For The Sultan”, 13 Ocak 1915.

The Register, “Assailants Not Turks, Denial By Prominent Ottoman”, 2 Ocak 1915.

The Register, “Assailants Not Turks, Denial By Prominent Ottoman”, 2 Ocak 1915.

The Register, "Not Turks", 8 Ocak 1915.

The Register, "Speedy Revenge", 2 Ocak 1915.

The Sydney Gazette and New South Wales Advertiser, "Death of Admiral Lord Viscount Nelson", 3 Ağustos 1806.

The Sydney Gazette and New South Wales Advertiser, "Extracts from the latest English Papers", 19 Haziran 1803.

The Sydney Morning Herald, "The Fight With The Turks", 4 Ocak 1915.

Truth, "Truth reported the Turkish insurgency". 19 Aralık 1920.

Whyte, Brendan, "Propaganda Eats İtself: The 'bulletin' and The Battle of Broken Hill”, Sabretche Journal, 2016, vol. 57, ss. 48-57. 
